\title{
NuTrI PuZZLE for the Month of JAN - APRIL 2017
}

\section{BREAK A PAZZLE USING VEGETABLES}

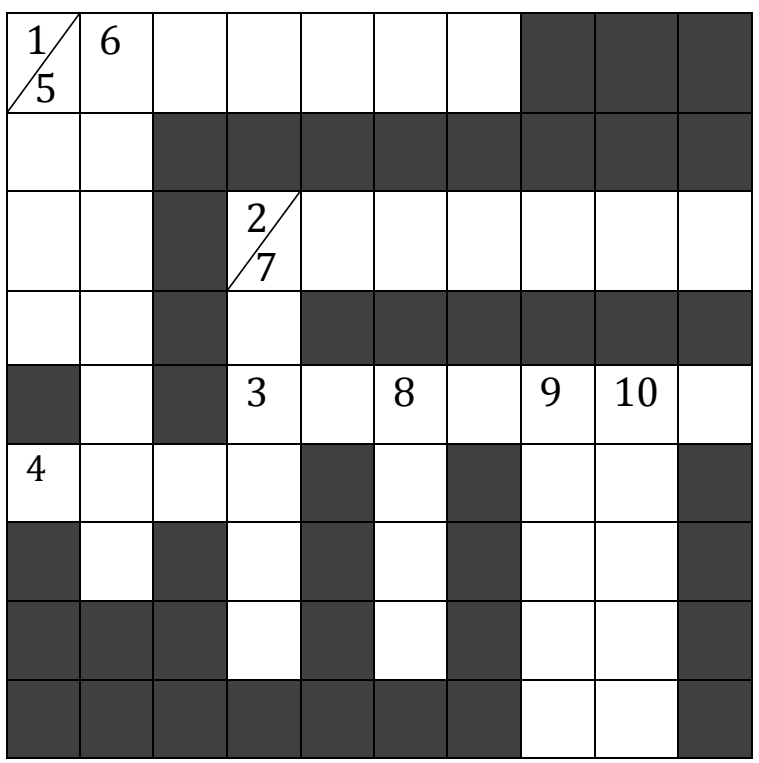

\section{ACROSS}

1. Also called as egg plant, rich in fiber [7]

2. A big vegetable rich in vitamin - A and fiber, grow in creeper [7]

3. It is a long tuber, starchy rich in fiber [7]

4. .......... gourd helps to reduce acidity, good for DM patients [3]

5. Grow in creeper, green color protein rich vegetables [4]

\section{UPS AND DOWN}

6. It is watery tuber, available in two colors \& rich in potassium [7]

7. A oval shaped starch tuber, loved by children [6]

8. Protein rich pulses, a small green balls [4]

9. A tuber in bulb shape [5]

10. A hot vegetable (last letter missing) [5] 